\title{
Reactions to the Future: the Chronopolitics of Prevention and Preemption
}

\author{
Mario Kaiser
}

Received: 19 October 2014 / Accepted: 11 June 2015 / Published online: 1 July 2015

(C) Springer Science+Business Media Dordrecht 2015

\begin{abstract}
How do we react to uncomfortable futures? By developing the notion of chronopolitics, this article presents two ways that we typically react to future challenges in the present. At the core of the chronopolitics of prevention, we find a striving for normalization and conservation of the present vis-à-vis dangerous futures. In contrast, the chronopolitics of preemption are geared towards a reformation, if not even a revolution of the present. Two case studies in the field of science and technology policy illustrate the difference between prevention and preemption. The debate on human embryonic stem cells illuminates prevention. The debate on nanotechnology clarifies preemption.
\end{abstract}

Keywords Chronopolitics · Prevention · Preemption · Technology assessment $\cdot$ Collingridge .

Nanotechnology $\cdot$ Stem cell debate

M. Kaiser $(\bowtie)$

Centre for Religion, Economy and Politics, University of

Basel, Basel, Switzerland

e-mail: mario.kaiser@unibas.ch

\section{Introduction}

Since the 1990s, the novel dispositif of preemptivity has arisen. ${ }^{1}$ It is a disposition, that is to say, an apparatus bodied forth by a heterogeneous ensemble of various policy documents, regulations and ordinances, timetravel movies, scientific predictions and prognoses, "governance," a strong decisiveness, and a peculiar sense of urgency. As a telling example, we may refer to the TV series 24 , broadcast a few weeks after the September 11 attacks (Fig. 1).

Due to its hidden protagonist, namely, time itself, the series foregrounds an almost incomparable sense of urgency. During the first seconds of each episode, a

\footnotetext{
${ }^{1}$ In an interview, Michel Foucault described the dispositif as "a thoroughly heterogeneous ensemble consisting of discourses, institutions, architectural forms, regulatory decisions, laws, administrative measures, scientific statements, philosophical, moral and philanthropic propositions" [1]. The extension of this notion is almost limitless and is of little help when it comes to identifying a particular dispositif. Foucault, however, adds, that a dispositif "has as its major function at a given historical moment that of responding to an urgent need" [1]. Against the background of a dispositif's strategic function, we may indeed characterize preemptivity as dispositif, because it is an answer to a variety of temporal problems, which slowly amalgamated in the 1990s of the last century: the fear of scarce resources in the future, the perception of slowly acting public authorities, the experience of fastspreading pathogens in a globalized society, etc. As an allied answer to these and similar problems, the dispositif emerged in the 1990s; however, it became visible in its entirety only after 9/11.
} 
Fig. 1 Split screen from the TV series 24 , episode 1 , season 1 (2001)

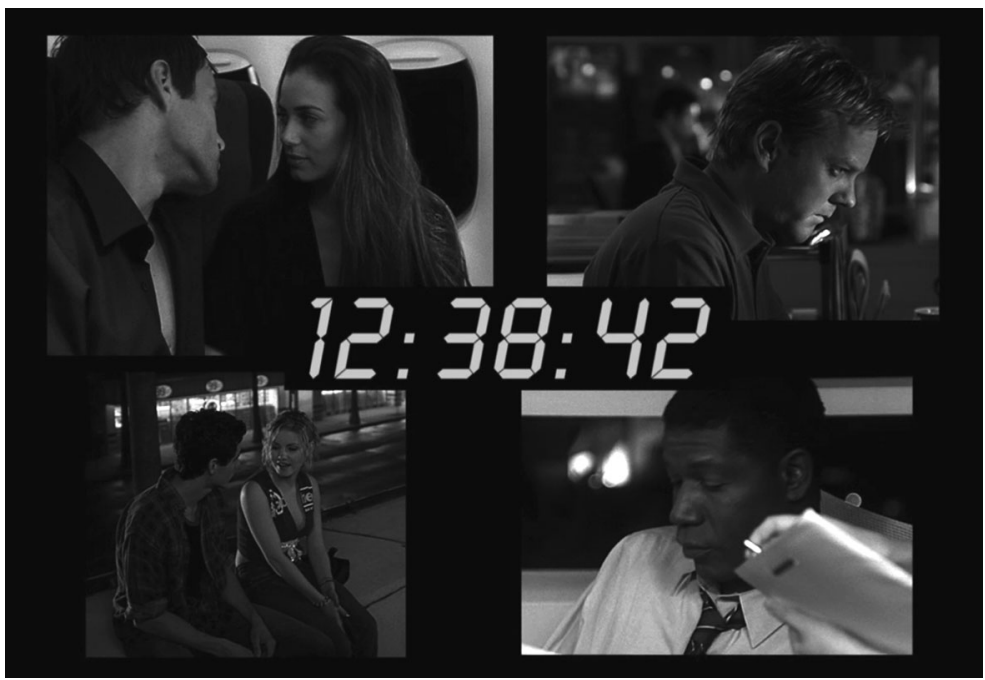

male voice-over states that the following events take place in real time and depict one hour in the life of Jack Bauer, the alleged protagonist of 24. Jack, a postCold War federal agent, has 24 hours left to prevent a serious terrorist attack. Collectively, all episodes of one season cover "the longest day in my life," that is, 24 hours fully packed with Jack's grueling, often questionable war on terror. However, as the real enemy does not so much consist of a misguided villain, but rather of the little time left, Jack's activities are nothing else than a war on time. Indeed, it is the remorseless passing of time that "forces" Jack Bauer to overrule moral principles, societal conventions, and legal laws.

Due to its blunt simplicity, the case of 24 reveals two important elements of the dispositif in question, both of temporal nature. If nothing is done, the US population faces a future that culminates in catastrophe. At the same time, Jack makes every effort to radically change the present.

During the last two decades, we have witnessed an escalation of announcements and maneuvers combining catastrophic futures with demands to reform the present. Preemptivity has traversed areas as diverse as popular culture, economic or foreign policy, and even the governance of emerging technologies. A growing number of scholars have begun to explore the formation of this dispositif. In her book Life as Surplus, Melinda Cooper unravels the various threads that have led to a kind of biopolitics ever more orchestrated by the notion of "catastrophic risk" [2]. In Marieke de Goede's study Speculative Security, preemptive strategies are analyzed vis-à-vis their difficult relation to the law [3]. By drawing upon the work of Giorgio Agamben and Michel Foucault, de Goede calls critical attention to preemption's violence - a violence discursively made plausible as the legitimate answer to almost unimaginable threats in the future. Besides the question of whether preemption operates inside or outside the law, some scholars have started to examine the temporal aspects of preemption [4-6].

In line with this temporal strand of research, my contribution portrays preemption as a novel form of chronopolitics that supplements the more familiar chronopolitics of prevention. Preemption and prevention represent different answers to the same problem: How should we react to catastrophic futures in the present? The solutions suggested by both chronopolitical types differ with respect to the present. At the core of prevention, we find the desire for a normalization and conservation of the present in relation to dangerous futures. In contrast, the chronopolitics of preemption are geared towards a reformation or revolution of the present.

Yet what exactly are chronopolitics? Paul Virilio introduced the term to indicate a shift from the politics of space (geopolitics) to the politics of time (chronopolitics) during the Cold War era. In order to analyze our presentday reactions to tomorrow's dangers, I will take up Virilio's notion, but define it anew. I take chronopolitics as the attempt to "govern the difference between the future and the present."

This definition entails the concept of time travel. In fact, governing the difference between the future and the present presumes, as a first step, divining catastrophic futures and then, as a second step, traveling back in time 
to control the present. Although hardly any policy documents that recommend particular measures vis-à-vis dangerous futures would explicitly regard time travel as a serious and legitimate instrument, such documents nevertheless carry out time travel experiments all the time, on a day-to-day basis. Above all, time travel is widely employed to bridge the gap between "knowing" the future and controlling the present.

In order to uncover the everyday practices of time travel that are embodied in policy documents, in politicians' speeches or in experts' advice, I present two canonical time travel movies as Weberian ideal types. The Terminator [7] illustrates the chronopolitics of preemption, while Back to the Future [8] embodies the chronopolitics of prevention. Although each movie prioritizes a particular mode of reacting to catastrophic futures, they both represent various blends of chronopolitical stratagems. Such chronopolitical mélanges are omnipresent in today's dispositif of preemptivity. Even in science and technology policy, we find various forms of chronopolitics striving for the legitimate control of the present: among them are preemption, with its ambition to radically change the present, and prevention, with its aim to normalize and conserve the present order.

\section{Defining Chronopolitics}

Thanks to Paul Virilio, we are able to talk about time as an avowed political resource. Against the background of the Cold War era and, more specifically, the decreased warning time preceding a nuclear attack, Virilio has emphasized a shift from geopolitics to chronopolitics. In warfare and politics alike, we have undergone a "transition from the state of siege of wars of space to the state of emergency of the war of time" [9]. Within this state of emergency, time has become an increasingly dwindling resource, leading to a present without any extension, except the moment of decision: "Contraction of time, the disappearance of the territorial space, after that of the fortified city and armor, leads to a situation in which the notions of 'before' and 'after' designate only the future and the past in a form of war that causes the 'present' to disappear in the instantaneousness of decision" [9].

Today's political imperatives, such as acting in a proactive way, not wasting any time, or taking action before it is too late, testify to Virilio's diagnosis that time has become a scarce political resource. At the same time, however, the ceaseless invocations of catastrophic futures, risks, and dangers bear witness to a strong futurism that has overrun our public authorities, our conceptions of how and when decisions have to be made, and even our innermost feelings.

To do justice to Virilio's notion, on the one hand, and to this disseminating futurism, on the other, it is worthwhile to define chronopolitics anew. If one follows Foucault's redefinition of the notion of government [10], which combines both top-down strategies of "governing others" and bottom-up methods of "governing the self," we may address chronopolitics as the governing of the difference between the future and the present. ${ }^{2}$

However, why is this definition useful? For one thing, it highlights a neglected aspect of current research concerning the construction of futures, specifically the question of how we react to our constructed futures. During the 1970s, the future had been established as a subject of research in the social sciences and humanities. Since then, programmatic approaches have time and again pleaded for a constructivist perspective denying that there are future facts. A quotation taken from Bell and Mau's Sociology of the Future illustrates this widely shared methodology: "[T]here are no future facts. However real our conceptions of it, our actions that will produce it, and the certainty of its coming, the future is open" [11]. Almost 30 years later, another volume reiterates this perspective: "As such, our purpose is to shift the discussion from looking into the future to looking at how the future as a temporal abstraction is constructed and managed, by whom and under what conditions" [12].

These and similar methodologies have given rise to a considerable spectrum of studies examining the ways that futures are or have been fabricated by discourses, expectations, actions, or images. Nevertheless, less attention has been given to the question of how our futures in turn affect our present-day actions, preferences, expectations, and wishes. By focusing on the effects that

\footnotetext{
${ }^{2}$ Attentive readers will immediately notice the omission of the past. In fact, there is no reason to exclude the past from the domain of chronopolitics except this: Concerning the past and its difference to the present, historians have presented by far more elaborated concepts such as politics of memory, identity politics, and politics of traditions. The past and its relation to the present constitute such a finely chiseled terrain of reflection, research, and theory that describing and analyzing it in the name of chronopolitics would be comparable to using a sledgehammer to crack a nut.
} 
our future has on the present, the ontology of the future changes slightly. It might still be the case that there are no future facts. However, when actors begin to react to particular future constructions, they react to them as if they were future facts. The definition of chronopolitics accounts for these reactions, given that it treats the future and the present as two different, more or less independent time domains. Drawing an analytical distinction thus helps to raise awareness of the discrepancy between future and present and, last but not least, of the effects resulting from this chronological difference.

The definition also seeks to complement Virilio's insights with a Foucauldian analysis of power and knowledge. Since Virilio conceptualizes time first and foremost as a scarce resource, his notion of politics is somewhat limited. It provides an understanding of the fact that various actors fight for this resource, try to exploit and diminish it, but it does not account for the less polemical facets of everyday politics. From Speed and Politics right up to The Administration of Fear, Virilio's writings pursue a conception of politics that is equivalent to the inversion of Clausewitz's formula that politics (or policy) is a mere continuation of war by other means $[9,13]$. Nonetheless, forging a connection between Foucault's notion of biopolitics and the concept of chronopolitics involves accrediting knowledge as an important political variable. In our advanced industrial societies, it is scientific knowledge that populates our future in the form of predictions, assessments, estimations, scenarios, foresights, and risks. Such a future expertise plays a far more important role in our personal as well as our public lives than do the real-time activities in a war scenario. It helps us to select and consume the right products, which are the sustainable and organic ones. Furthermore, it shapes our understanding of why our personal pensions might be in danger, why we have to look for nanotechnology in our clothing, or why we cannot expect a steep improvement in the employment market. We live in the midst of a chronopolitical age in which we daily decide how to react to scientifically explored futures.

Finally, the definition is plastic enough to capture not only preemption and prevention but also additional forms of chronopolitics. ${ }^{3}$ In fact, the definition catches

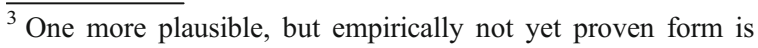
evitation. It would consist of a kind of intentional ignorance towards risky futures with the aim to avoid any actions in the present. If Jack Bauer is the epitome of preemption, Ivan Goncharov's Oblomov might exemplify such a refusal of the future.
}

a glimpse of a comprehensive inventory of the timedependent power formations that make up the chronopolitical constitution of our time. To get an idea of the most dominant configurations as well as of the modes these convince or persuade us to act as we do is not merely a self-sufficient endeavor at the intersection of the social sciences and humanities. Rather, it forms the basis for a detailed critique of particular chronopolitical interventions. Such a critical evaluation seems all the more advisable as the configuration of preemption regularly seduces us, just like Jack Bauer, to act in a controversial, semilegal manner.

\section{Time, Knowledge, and Control: the Necessity of Time Travel}

Since it entails comparing the future and the present in a way that would only be possible if we were able to travel between these two time spheres, defining chronopolitics as governing the difference between future and present seems absurd. Still, we have become so accustomed to time travel in our daily decisions that it often escapes our attention. Time travel plays a crucial role insofar as it bridges the gap between what we know or believe to know about the future and our present abilities to exert control and power. How urgently we need time travel becomes evident in the Collingridge dilemma. It serves as a simple model because it configures three relevant variables in a comprehensible way: time, knowledge, and control. After having investigated the model and its implications, we will build some ideal types, in Max Weber's sense, of the most dominant forms of time travel that we use to solve our daily time-knowledgecontrol dilemmas.

In his Social Control of Technology, David Collingridge presents a dilemma which has become known and often cited as the Collingridge dilemma: "[A]ttempting to control a technology is difficult, and not rarely impossible, because during its early stages, when it can be controlled, not enough can be known about its harmful social consequences to warrant controlling its development, but by the time these consequences are apparent, control has become costly and slow" [14].

The dilemma consists of the precarious ratio of control and knowledge. At moment $t_{1}$, at the beginning of a technological development path, we have maximal control, but almost no knowledge. At a later moment $t_{2}$, the ratio has inverted in favor of knowledge, but at the cost of control (Fig. 2). 
Fig. 2 The Collingridge dilemma of control and knowledge

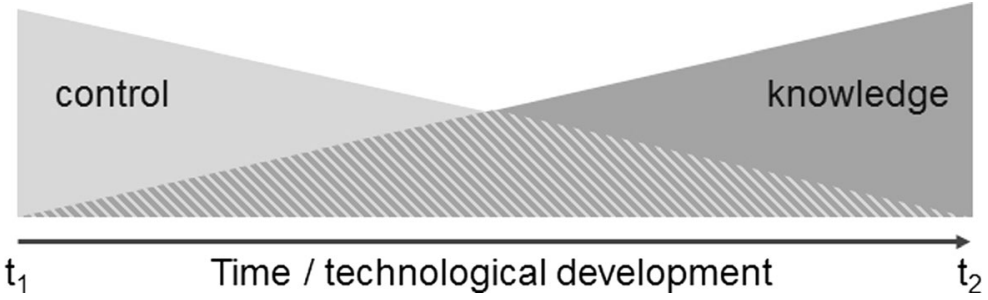

In the fields of technology assessment, ethics of technology, or science and technology policy, the Collingridge dilemma represents a necessary evil. It is highly contested and criticized for its assumption of a linear technological development. At the same time, however, it is used as a template for specifying new solutions to these issues: When is the right time to control the technology in question? How can we get knowledge about the future course of a specific technology? What instruments of future knowledge production such as foresight, participatory anticipation, or prognosis are suitable?

There are various work arounds for this dilemma. A wait-and-see approach, for example, relies on more knowledge in the future, while a proactive approach bets on the right decisions in the present. If compared with the one and only answer, which is time travel, such solutions are at best makeshift. Time travel would allow us to travel back to the present and control the course of events with all the knowledge from the future. Thanks to time travel, we would no longer be confronted with the trade-off between control and knowledge (Fig. 3).

No white paper, action plan, or policy document would ever refer to time travel as a viable instrument to overcome chronopolitical dilemmas. Still, the same documents and doctrines are almost weighed down by linguistic maneuvers that attempt to break through the barrier between the future and the present.
In 2003, the UK Economic and Social Research Council published The Social and Economic Challenges of Nanotechnology [15]. The document's summary performs several acrobatic leaps across time. It begins with the concession that "conceptions of nanotechnology are not always clear or indeed agreed upon" [15]. Next, it states that "[n]anotechnology will produce economic and social impacts on three broad timescales." Faced with such future "facts" and the concern "that there will be a backlash against nanotechnology akin to that over genetic modification," the summary then comes to the conclusion that social science should "take a role focused on promoting social awareness and acceptance of nanotechnology."

In the course of a few paragraphs, the text starts from an uncertain present (nanotechnology is not always clear), travels into a practically certain future with almost known impacts (nota bene: on three broad timescales), and finally returns to the present with some recommendations at hand (the social science should...). By virtue of acquiring such knowledge from the future, posturing as if it could therefore be known how to control the present of nanotechnology, the summary would appear to solve the Collingridge dilemma.

This laborious attempt to govern the difference between the future and the present becomes eclipsed by just a few sentences that the US president George W. Bush used to explain what later became known as the Bush doctrine: "If we wait for threats to fully materialize, we will have waited too long. (Applause.) [...] We
Fig. 3 The solution of the Collingridge dilemma

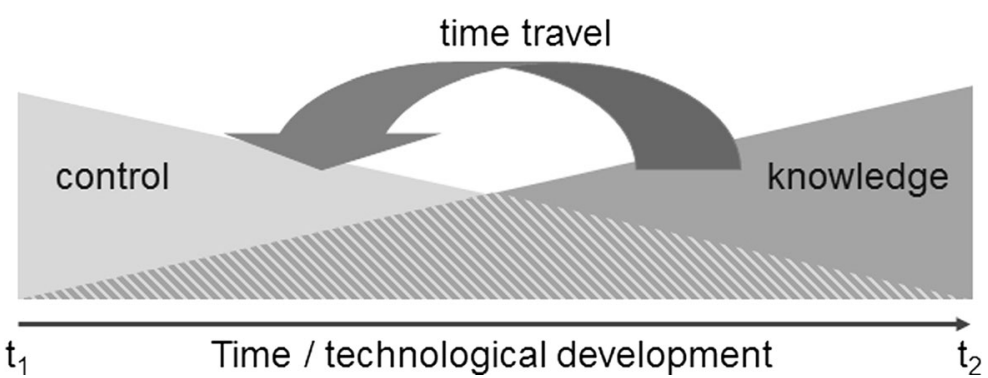


must take the battle to the enemy, disrupt his plans, and confront the worst threats before they emerge. (Applause.) [...] And our security will require all Americans to be forward-looking and resolute, to be ready for preemptive action when necessary to defend our liberty and to defend our lives" [16, my emphasis].

In contrast to the time travel undertaken to control nanotechnology, Bush's speech does not so much rely on any particular knowledge acquired in the future, but rather on a providence-like certainty of how things generally evolve in the future. The threats we perceive in the present are just the tips of terror icebergs that will crystallize in the future. Regarding this certainty about the future, an analogy can be made with Philip K. Dick's 1956 short story Minority Report, which was adapted as a film in 2002. In both of these cases, the Bush doctrine and the Dick story, future crimes are foreseen by gifted persons in the present, enabling us to change the course of events before "we will have waited too long."

These are just two examples from a long list of policy doctrines, governance proposals, and white papers that try to govern the discrepancy between the future and the present. Despite many differences, all of them aim to link knowledge from the future and control in the present by traveling back and forth in time.

\section{Chronopolitical Ideal Types}

How can we analyze our quotidian practices of time travel without losing ourselves in a discussion as to whether such travel is possible at all? Even without a time machine, our political policies and discourses repeatedly prove that such time travel is possible and that it is carried out to govern the difference between the future and the present.

In his methodological writings, Max Weber elaborates on the concept of "ideal type" as a means to generalize and interpret the phenomena encountered in research. An ideal type is an idea or a mental construct achieved by "the one-sided accentuation of one or more points of view and by the synthesis of a great many diffuse, discrete, more or less present and occasionally absent concrete individual phenomena" [17]. Such a type is not determined to act as a representation of reality, although it has to be adequate to reality. It is a utopia, as Weber himself puts it, and as such it has the purpose to discipline the researcher to perceive phenomena in a new light, from a new perspective or in a new context.
To better characterize the chronopolitics of preemption and prevention, I will make recourse to ideal types already encoded in popular culture. From the beginning of the 1980s, Hollywood experienced a boom of time travel movies. These films include, for example, The Philadelphia Experiment [18], the Back to the Future trilogy [8, 19, 20], the Terminator series [7, 21-23], Flight of the Navigator [24], Bill \& Ted's Excellent Adventure [25], and some installments from the Star Trek franchise, such as Star Trek IV: The Voyage Home [26] and Star Trek: First Contact [27].

Two of these movies exquisitely manifest the latent chronopolitical structures of the prevailing discourses on future consequences, risks, and dangers. The movie Back to the Future (1985) illustrates the chronopolitical configuration of prevention, while The Terminator (1984) serves us as a paradigmatic example for preemption. Yet even as they represent ideal types of the chronopolitical imagination, they also entail traces of opposing chronopolitics.

In Back to the Future, the teenager Marty McFly accidentally travels from the year 1985 back to the year 1955. After Marty's arrival in the past, his mother proposes to fall in love with her own future son (Fig. 4). As this inversion of the Oedipus complex would cause the nonexistence of Marty in the future, he does his utmost to bring his biological parents together. His context management succeeds, so that he can travel back to the future without risking his existence.

It is precisely Marty's knowledge about the girl Lorraine destined to become his mother that prompts Marty's chronopolitical attempt to control the present of the year 1955. Marty has to rearrange the present as if he had never arrived there. Accentuated by the peaceful, petty bourgeois, and chaste atmosphere of the 1950s, his strategies aim at normalization and conservation of the

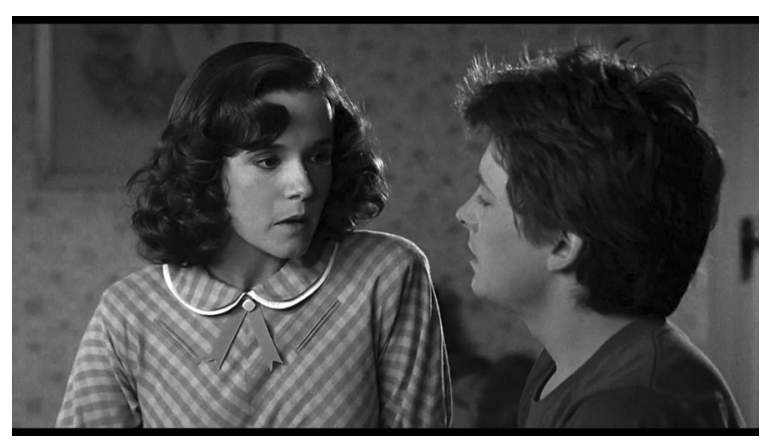

Fig. 4 Marty McFly meets his mother 
present course of events. The innocent status quo of this era, threatened by Marty's arrival, has to be rebuilt and consecrated anew.

Despite the emphasis on prevention, the movie partially comprises preemptive chronopolitics as well. After his return to the future, Marty encounters an improved situation. His father is now a successful science fiction writer, Lorraine is physically fit instead of an alcoholic, and Biff Tannen is a subordinate of Marty's parents. Thus, Marty has not only normalized the past but also changed it in favor of his family.

Still, the preservationist and conservative attitude in Back to the Future is in stark contrast to the warlike climate of the first movie of the Terminator franchise. Although Back to the Future and The Terminator present almost identical narrative structures, they differ precisely in their attitudes towards the present. In The Terminator, the plot once again starts in the future, this time in the year 2029, when artificially intelligent machines attempt to eliminate the human race. Thanks to John Connor, leader of the resistance, mankind regains hope despite the desperate battle against the machines. This is reason enough for the machines to send a Terminator back to the year 1984 to kill John Connor's mother (Fig. 5). Although the Terminator falls down on his job, the present of 1984 becomes a site of dystopia reminiscent of George Orwell's Nineteen Eighty-Four. In sharp contrast to the innocent present of the $1950 \mathrm{~s}$ in Back to the Future, the audience is confronted with a present in which the future existence of humankind itself is at stake. Thus, the present is depicted as a highly contingent terrain chosen by the machines for a radical reformation, an attempt to dramatically alter the course of events. The machines' knowledge of the human resistance in the future prompts them to control the present by taking a proactive and reforming

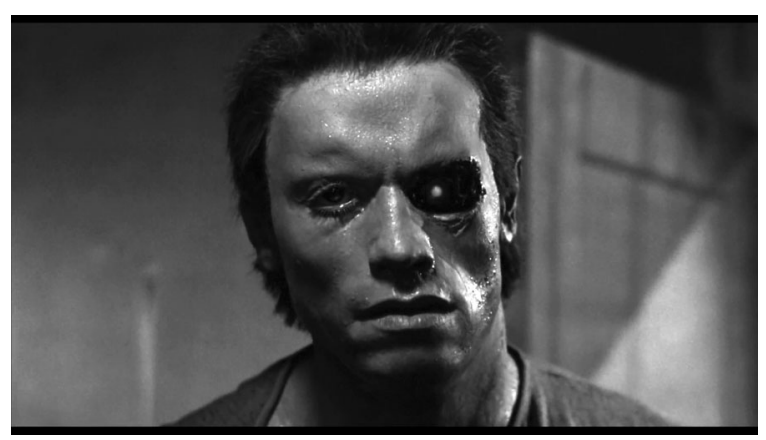

Fig. 5 Terminator. Half future, half present approach instead of a conservative and normalizing one.

Although the Terminator's preemptive strategy represents the raison d'être for the story, the film ends with a victory of prevention over preemption. The Terminator itself is ultimately terminated by Kyle Reese, who was also sent back from the future, notably by John Connor, to prevent the massive course correction the Terminator was charged with.

Notwithstanding the chronopolitical mélange represented in both films, it is specifically the different stance towards the present vis-à-vis dangerous futures that makes the difference between prevention and preemption, between Marty's predominantly conservative handling of the present and the Terminator's ambition to reform it. Further dissimilarities that can be deduced from this central distinction are indicated in Table 1.

The difference between prevention and preemption is not only a question of the instruments we choose to modify the present, namely, normalizing procedures in the first case versus reforming procedures in the second. Whether we react to uncomfortable futures in a preventive or preemptive way is a matter of deep-seated convictions, if not metaphysical attitudes regarding the things to come. In the preventive case, the untouched chain of events leading into the future is deemed as normal or regular. Only if we touch this course do we run the risk of ending in tragedy. Accordingly, the chronopolitics of prevention seek to prohibit any intervention in this process in order to avoid a "slippery slope," "a crossing of the Rubicon," or "an opening of Pandora's box." For this purpose, the normal course of events has to be conserved and, first of all, normalized.

In contrast to the belief that everything will be fine as long as the fragile chain of things is left untouched, the metaphysical belief underlying the chronopolitics of preemption assumes that the future will inevitably end in tragedy or in a state of emergency. Only if we drastically change the course of events, only if we do not wait too long, and only if we act "right now" are we able to bend the course of events into a shape that provides us with a surplus of a humane future.

The central "metaphysical" differences can be indicated with a sketch highlighting the regular as well as the feared course of events in both ideal types (Fig. 6). The extraordinary futures are projected ones. The corrected futures are open futures, however, without the anticipated state of emergency. 
Table 1 Comparison between prevention and preemption

\begin{tabular}{lll}
\hline & Prevention & Preemption \\
\hline Paradigmatic movie & Back to the Future (Zemeckis, 1985) & The Terminator (Cameron, 1984) \\
Means of controlling the present & Conservation and normalization of the present & $\begin{array}{l}\text { Reformation and revolution of the present } \\
\text { Character of political action }\end{array}$ \\
Slogan & Prudent, prohibiting, cautious & Proactive, activist, reformatory \\
& Principiis obsta! "Resist the beginnings!" & $\begin{array}{l}\text { Si vis pacem futurum, para praesentiam } \\
\text { "If you want peace in the future, prepare } \\
\text { the present" }\end{array}$ \\
\hline
\end{tabular}

\section{Prevention}

The debate on human embryonic stem cells provides an exemplary reservoir of time travel practices that correspond to the way Marty McFly solved the dilemma of present control and future knowledge.

In 2001, Johannes Rau, the former president of Germany, gave a much-noticed speech with the title "Wird alles gut? - Für einen Fortschritt nach menschlichem Maß" [Will everything turn out well? For progress befitting humanity]. With this talk, Rau took up a position against the permission of research on human embryonic stem cells [28]. Not only was it the moral authority of the president that made this speech prominent, but also the usage of a strong metaphor which was subsequently cited over and over again [29]. Rau compared the permission to crossing the
Rubicon. To be more specific, he claimed that there is "enough room on this side of the Rubicon." With the allusion to a topological boundary, Rau thus closed a frontier between the present and the dangerous futurea frontier that should not be crossed. The dreaded passage into the future is emphasized by another argument that equally connects the future and the present in a problematic way. It is a version of the slippery slope argument that invokes the slogan of prevention in an almost crystalline form: "resist the beginnings." In Rau's words: "Whoever begins to instrumentalize human life, whoever begins to discriminate between worth living and not worth living, is in fact on a plane without stop" [28, my translation].

With this speech, Rau performed the chronopolitics of prevention in a typical manner. Firstly, by hinting at the sufficient room on this side, he consecrated the
Fig. 6 The ordinary and extraordinary futures of prevention and preemption
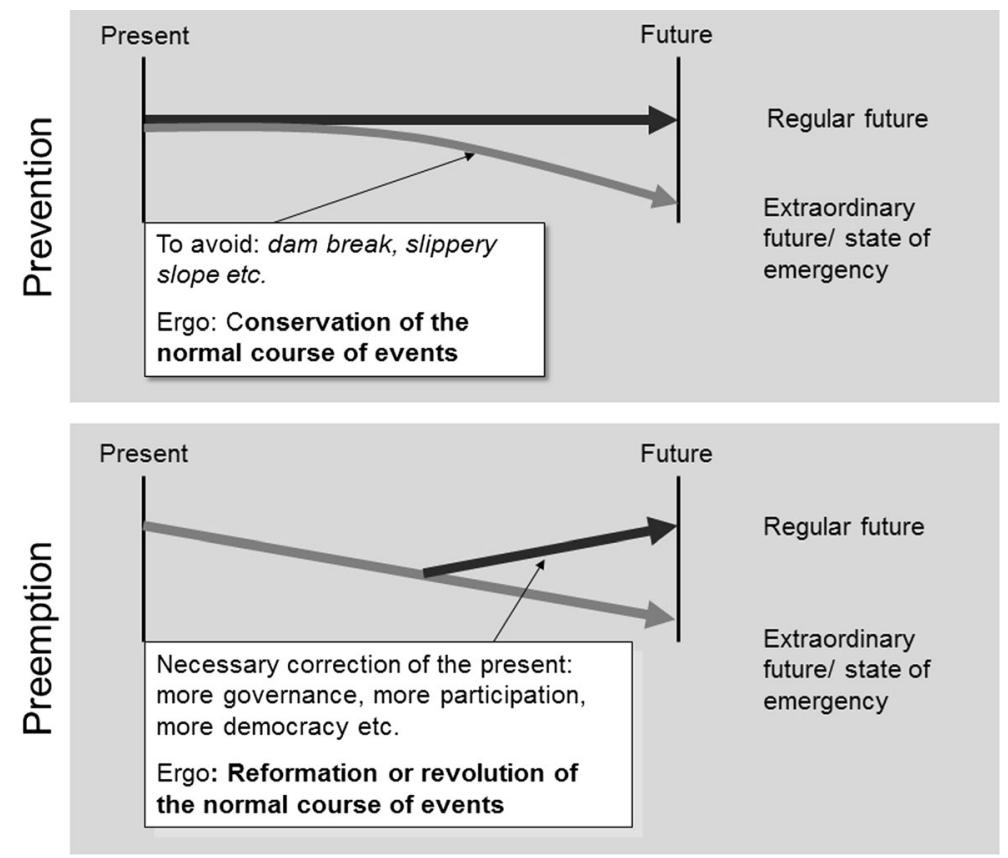
present in a normalizing and conserving way. Secondly, the character of his chronopolitical intervention is prudent, prohibiting, and cautious. He erects an almost religious ban on those who begin to violate the sacred present by taking steps into a eugenic future. The taboo on deviating from the present course is comparable to the taboo of Marty McFly's touching his own mother. Thirdly, since he traveled there in the past, Rau knows the future. He convincingly revives the past future of Nazi Germany and thus reminds us of the steps taken in the wrong direction.

With this intervention into the political future of life itself, Rau is not alone. In Germany, the debate on human embryonic stem cells has seen numerous chronopolitical maneuvers of the preventive sort. Another clear example is Jürgen Habermas' intervention in this dispute. In his book Die Zukunft der menschlichen Natur: auf dem Weg zu einer liberalen Eugenik? [The Future of Human Nature: Towards Liberal Eugenics?], Habermas unfolds his line of argument with prospects of a future society whose descendants will have been cheated out of their rights to oppose their parents' generation [30]. He derives the right to challenge parents in an open and non-coercive play of question and answer from the gattungsethisches Selbstverständnis der Kontingenz der Zeugung. In other words, it is our self-understanding of newborns being the contingent result of the genetic recombination of their parent's genomes that is in danger. Therefore, Habermas distinguishes between "born" and "designed" in order to show that preimplantation diagnostics or research on embryonic stem cells would drastically reduce the possibilities of objection in the younger generation. The decisions made in the case of a designed baby restrict its future capacity to understand itself as selfdetermined and autonomous.

With this uncomfortable future in mind, Habermas travels back into the present with a mission to block developments in the dreaded direction. In line with the slogan of prevention- "resist the beginnings!"- - he warns against permitting preimplantation diagnostics and research on human embryos: "From this perspective, both controversial innovations show us from the beginning how our modus vivendi could be altered if interventions that change genetic attributes became customary" [30, my translation].

Like Rau, Habermas seeks to normalize and conserve the status quo vis-à-vis the envisioned future that jeopardizes the normality of biological contingency in human reproduction. Moreover, both chronopolitical interventions share an underlying metaphysical attitude towards the difference between the future and present. As long as the present remains untouched, the future is safe. Nevertheless, as the present is regarded as highly fragile, a small change may provoke an unstoppable chain reaction.

In the debate on human embryonic stem cells, preventive forms of governing the difference have not been limited to Germany. Around the globe, voices warned against steps in the wrong direction. With high regularity, these warnings have been expressed in the form of slippery slope arguments. The former Bush administration used this kind of argument in order to ban public funding of research that destroys human embryos in harvesting new stem cells: "Stem cell research takes place on a slippery slope of moral concern where much biomedical research is and will be conducted. We must keep our ethical footing. Government has a clear duty to promote scientific discovery - and a duty to define certain boundaries" [31].

Interestingly, high-ranking representatives of the US Catholic Church have regarded exactly this decision as a first step on a slippery slope. In an article containing statements of reaction, Cardinals McCarrick and Maida as well as Monsignor Strynkowski expressed their regrets over the president's permission of research on already existing stem cell lines, and for this, they explicitly suggested that the slippery slope has already been stepped on [32].

For illustrating the chronopolitics of prevention, some key moments in the debate on human embryonic stem cells have been chosen in order to reveal certain sophisticated forms of time travel and advanced chronopolitical maneuvers. At their core, we mostly find a striving for normalization and conservation of the present. It is a desire motivated by the day-to-day practices of time travel in which one or another future has been envisioned and explored.

\section{Preemption}

The announcement of a preemptive strike probably marked the first time when the notion of preemption left the secretive military domain and entered the public sphere [16]. It has triggered some bafflement concerning the distinction between a preventive and a preemptive 
war. Concerning preventive wars, there is at least some legitimation [33]. But what about preemptive wars? The legal scholar Frederic Kirgis has proposed the criterion of "imminent threat" to discriminate between a preventive war, which reacts to an imminent threat, and a preemptive war, which replies to a more distant one [34]. However, this "solution" has provoked further, almost scholastic debates on the exact meaning of imminent threat $[35,36]$.

Equipped with the two chronopolitical forms depicted in Back to the Future and The Terminator, we may attribute the difference between preventive and preemptive wars to a criterion other than imminent threat. A preventive strike seeks to avoid a war in order to save the normal course of events. The foreign threat corresponds to the first step on a slippery slope - a step that has to be annulled by preventive measures in order to save and conserve the present order. On the contrary, in the case of a preemptive strike, the foreign threat is conceived of as a future fact or at least as a symptom of a war which has been prepared by the opponent long ago. Only a massive reorganization of the present order permits preventing the catastrophe in time. Thinking and deciding along the lines of preemption brings us to the logic of "creating new facts before it is too late."

The notion of a preemptive strike, however, should not incite us to solely locate preemption in the context of warfare or foreign policy. The metaphysical attitude towards the present, rendering it as locus of intervention, reformation, or radical experimentation, is gaining acceptance in far distant fields. Nanotechnology represents an interesting case insofar as the engagement with the future consequences, and implications of the technology have begun before the technology itself has assumed a clear shape. Academic fields such as science studies or applied ethics, private organizations such as reinsurance companies, and public institutions such as national institutes for technology assessment have contributed to the formation of an "assessment regime" that encourages new proposals for dealing with the future of nanotechnology [37]. This early assessment has turned two established expectations upside down. On the one hand, the future of nanotechnology has become almost better known than its present. On the other hand, the explored future of nanotechnology has triggered several recommendations regarding how we may rearrange things in the present-formidably in the name of governance.
The whole discursive order may be characterized as preemptive. Nevertheless, particular policy proposals within this all-embracing nanotechnology engagement deserve closer attention since they articulate a preemptive solution in a straightforward manner.

In the midst of nanotechnology's assessment hype, the philosophers Jean-Pierre Dupuy and Alexei Grinbaum called for an alternative assessment approach [38]. In their article "Living with Uncertainty," Dupuy and Grinbaum explicitly dissociate themselves from preventive measures, since these-for principal reasons - always come too late. Instead of prevention, the authors recommend an approach that proceeds on the assumption that a catastrophe will occur. The presupposition of a disaster is regarded as the only way society will be able to avert this particular catastrophe:

The methodology of ongoing normative assessment can also be viewed as a conjunction of inverse prescriptions. This time, instead of an optimistic but credible image of the future, one should wish to obtain at every moment of time an image of the future sufficiently catastrophic to be repulsive and sufficiently credible to trigger the actions that would block its realization. [...] [A] catastrophe must necessarily be inscribed in the future with some vanishing, but non-zero weight, this being the condition for this catastrophe not to occur. The future, on its part, is held as real. This means that a human agent is told to live with an inscribed catastrophe. Only so will he avoid the occurrence of this catastrophe. [...] A damage that will not occur must be lived with and treated as if inevitable: this is the aporia of our human condition in times of impending major threats [38].

Besides the critique on prevention, the "precautionary principle" serves as a further occasion for Dupuy and Grinbaum to propose their catastrophic approach. In fact, the discussion around this very principle has deeply inscribed itself in the extensive engagement with nanotechnology. For instance, the think tank Center for Responsible Nanotechnology published a short statement in 2003 on the application of the precautionary principle to nanotechnology [39]. The paper distinguishes between a passive and an active understanding of precaution, concluding that the passive version is inappropriate when it comes to dealing with nanotechnology, as it demands 
no action when facing extreme risks in the future. Only measures reminiscent of radical reformation of the present order are deemed suitable to steer things in the right direction.

Surely, there are differences between Dupuy and Grinbaum's catastrophic approach and the Center for Responsible Nanotechnology's short statement. However, the two interventions share the belief that only a proactive and preemptive form of governance is capable of avoiding the "impeding major threats" awaiting us in the future. We can no longer subsume the proposals under the slogan of prevention, "resist the beginnings." Rather, these proposals more resemble the Late Latin proverb si vis pacem, para bellum, that is, "if you want peace, prepare for war." If we bring in the chronopolitical dimension, both statements seem to match the motto of preemption perfectly, namely, si vis pacem futurum, para praesentiam.

It seems that without imputing time travel, some discursive interventions do not make sense at all or are at least highly contradictory. The plea for "anticipatory governance," for example, reveals such an ambivalent line of argumentation [40]. In line with a constructivist stance towards the future, it argues for agnosticism concerning the things to come. On an epistemological level, we find concessions like this one: "For, although action and outcomes are emergent qualities of human choice and behavior, they rarely, if ever, proceed from certainty or prediction, and neither are they based on simple intentions of individual actors or policies. Rather, as the concept of 'anticipation' is meant to indicate, the co-evolution of science and society is distinct from the notion of predictive certainty" [40].

This view of the future becomes foiled, however, as soon as the question comes up as to how we should act in view of this uncertainty. At this very moment, the recommended way of proceeding only makes sense if the formerly adjured uncertainty is interpreted as a certainty that some things, whatever they are, will go wrong in the future: "Anticipatory governance comprises the ability of a variety of lay and expert stakeholders, both individually and through an array of feedback mechanisms, to collectively imagine, critique, and thereby shape the issues presented by emerging technologies before they become reified in particular ways" [40, my emphasis].

The emphasized relative clause performs the very time travel that the Terminator had already gotten over and done with 30 years ago. He, too, traveled from an already reified future to the present of the year 1984, in order to imagine, criticize, and shape the issues before they could become reified in the birth of John Connor. On an epistemological level, the proposal of anticipatory governance assumes that the future has not yet taken place. On an action-related level, conversely, the same proposal makes recommendations as if the future had already happened and only a turn towards governance could forestall the envisioned future.

Since most of the chronopolitical efforts dealing with the future/present difference of nanotechnology still aim at normalization and conservation of the present order, it would be a mistake to insinuate that science and technology policy is currently undergoing a shift from prevention to preemption. Nevertheless, the few occurrences of preemptive chronopolitics within the current assessment regime of nanotechnology enjoy remarkable visibility. They seem to resonate with a climate of preparedness, which in turn has merged into the dispositif of preemptivity. Here, we find some family resemblances: a fear of being too late, a strong duty to act right now, and a striving to reform or revolutionize the present order.

\section{Discussion and Outlook}

Prevention and preemption represent two chronopolitical configurations by which we currently solve timedependent problems. To be precise, prevention and preemption are ideal types won by the "one-sided accentuation of one or more points of view and by the synthesis of a great many diffuse, discrete, more or less present and occasionally absent concrete individual phenomena" [17]. Their status as ideas or Gedankenbilder may cause problems in empirical research since the social and political reality is often too diffuse to allow for an easy identification. Against the background of the two ideal types of chronopolitics, however, we may specify some criteria helpful for distinguishing them.

The first distinction consists of the chain of events connecting the future with the present. If this chain is believed to inevitably lead to disaster as long as nothing is done to prevent this development, it is highly likely that we are concerned with a form of preemption. On the other hand, in the case of prevention, the route to the future could turn out to be very fragile, but it still leads into a more or less acceptable future - unless we touch this fragile bond between the present and the future. 
The second difference rests on the character of the proposed political action with which we have to react to one or another future. A cautious, prudent, and prohibiting style indicates preventive chronopolitics. In contrast, a preemptive form emphasizes a proactive, decisive, and rapid way of handling the discrepancy between the future and present.

Last but not the least, prevention and preemption differ with respect to the way the present order is subjected to political action. It is only in the case of prevention that the present is saved, conserved, and normalized as "locus of reality" [41]. Such a metaphysical conception is, of course, the result of the very actions aimed at positioning the present in such a quasi-sacred status. Often, an accordingly normalized present becomes the starting point for a further "freezing" by means of standardization processes. This kind of immobilization of the present is absent in the case of preemption. Here, the present ever more assumes the shape of a "locus of intervention": a place to be urgently reformed, changed, or transformed.

An analysis of chronopolitics, however, is not an endeavor that ends with these two configurations. Rather, it is an effort to identify further ideal types on the long way to a comprehensive inventory of the most dominant power/knowledge formations that make up the chronopolitical constitution of our time.

Ultimately, an analysis of chronopolitics may even provide a starting point for a critical discussion of particular forms of politics. In this vein, we may ask crucial questions about the compatibility of preemptive chronopolitics with democratic procedures and processes, because democratic governance requires time - and time is a scarce resource under the regime of preemption.

Even though the dispositif of preemptivity seems to pervade ever more areas of our private and public life, the narrative of The Terminator brings one important issue to mind: we may always draw on different, even opposing forms of chronopolitics in order to determine our reactions to the future.

Acknowledgments For helpful comments, I thank Corinna Virchow, Beatrix Rubin, Andreas Lösch, Marcus Müller, Christopher Coenen, two anonymous reviewers, and notably Colin Milburn. The paper is a revision and extension of a short draft published in Technikfolgenabschätzung-Theorie und Praxis 23:2 (2014) entitled Chronopolitik: Prävention und Präemption.

\section{References}

1. Foucault M (1980) The confession of the flesh. In: Gordon C (ed) Power/knowledge. Selected interviews and other writings 1972-1977. Pantheon Books, New York, pp 194228

2. Cooper M (2007) Life as surplus: biotechnology and capitalism in the neoliberal era. University of Washington Press, Seattle

3. de Goede M (2012) Speculative security: the politics of pursuing terrorist monies. University of Minnesota Press, Minneapolis

4. Anderson B (2010) Preemption, precaution, preparedness: anticipatory action and future geographies. Prog Hum Geogr 34:777-798

5. Opitz S, Tellmann U (2015) Future emergencies: temporal politics in law and economy. Theory Cult Soc 32:107-129

6. Kaiser M (2015) Über Folgen: Technische Zukunft und politische Gegenwart. Velbrueck, Weilerswist

7. Cameron J (1984) The Terminator. Orion Pictures

8. Zemeckis R (1985) Back to the Future. Universal Pictures

9. Virilio P (1986) Speed and politics: an essay on dromology. Columbia University, New York

10. Foucault M (1988) Technologies of the self. In: Martin LH, Gutman H, Hutton PH (eds) Technologies of the self: a seminar with Michel Foucault. University of Massachusetts Press, Amherst

11. Bell W, Mau JA (eds) (1971) The sociology of the future: theory, cases, and annotated bibliography. Russell Sage, New York

12. Brown N, Rappert B, Webster A (eds) (2000) Contested futures: a sociology of prospective techno-science. Ashgate, Aldershot

13. Virilio P (2012) The administration of fear. Semiotext(e), Los Angeles

14. Collingridge D (1980) The social control of technology. St. Martin's Press, New York

15. Wood S, Jones R, Geldart A (2003) The social and economic challenges of nanotechnology. Economic and Social Research Council, Swindon

16. Bush GW (2002) President's remarks. Graduation speech. West Point United States Military Academy, West Point

17. Weber M (2011) 'Objectivity' in social science and social policy. In: Weber M, Shils EA, Finch HA (eds) Methodology of social sciences. Transaction Publishers, New Brunswick, pp 49-112

18. Raffill S (1984) The Philadelphia experiment. Pictures, New World

19. Zemeckis R (1989) Back to the Future Part II. Universal Pictures

20. Zemeckis R (1990) Back to the Future Part III. Universal Pictures

21. Cameron J (1991) Terminator 2: Judgment Day. Carolco Pictures

22. Mostow J (2003) Terminator 3: Rise of the Machines. Action, Sci-Fi, Thriller. C-2 Pictures

23. McG (2009) Terminator Salvation. Action, Drama, Sci-Fi, Thriller. Halcyon Company

24. Kleiser R (1986) Flight of the Navigator. Family, Adventure, Sci-Fi. Walt Disney Pictures 
25. Herek S (1989) Bill \& Ted's Excellent Adventure. De Laurentiis Entertainment Group

26. Nimoy L (1986) Star Trek IV: The Voyage Home. Paramount Pictures

27. Frakes J (1996) Star Trek: First Contact. Paramount Pictures

28. Rau J (2001) Wird alles gut?-Für einen Fortschritt nach menschlichem Mass. Berliner Rede May 18, Berlin

29. Nerlich B (2005) "A river runs through it": how the discourse metaphor crossing the Rubicon structured the debate about human embryonic stem cells in Germany and (not) the UK. Metaphorik 8:71-104

30. Habermas J (2001) Die Zukunft der menschlichen Natur: Auf dem Weg zu einer liberalen Eugenik? Suhrkamp, Frankfurt am Main

31. Bush GW (2001) Stem cell science and the preservation of life. The New York Times, August 12, sec. Opinion

32. Fiorenza J, Keeler W, Rigali J, D’Arcy J, Law B, O'Malley S, Flynn H et al (2001) Reaction to President Bush's decision on embryonic stem-cell research. Origins 31:207-13

33. Walzer M (1977) Just and unjust wars: a moral argument with historical illustrations. Allen Lane, London
34. Kirgis FL (2002) Pre-emptive action to forestall terrorism. Newsletter of the American Society of International Law

35. Sofaer AD (2003) On the necessity of pre-emption. Eur J Int Law 14:209-226. doi:10.1093/ejil/14.2.209

36. Brown C (2003) Self-defense in an imperfect world. Eth Inter Affairs 17:2-8

37. Kaiser M, Kurath M, Maasen S, Rehmann-Sutter C (eds) (2010) Governing future technologies: nanotechnology and the rise of an assessment regime. Springer, Dordrecht

38. Dupuy J-P, Grinbaum A (2005) Living with uncertainty: toward the ongoing normative assessment of nanotechnology. Techné: Res Philos Technol 8:4-25

39. Phoenix C, Treder M (2014) Nanotechnology: precautionary principle analyzed. Center for Responsible Nanotechnology. http://www.crnano.org/precautionary.htm. Accessed March 23

40. Barben D, Fisher E, Selin C, Guston DH (2008) Anticipatory governance of nanotechnology: foresight, engagement, and integration. In: Hackett EJ, Amsterdamska O, Lynch M, Wajcman J (eds) The handbook of science and technology studies, 3rd edn. MIT Press, Cambridge, pp 979-1000

41. Mead GH (1959) The philosophy of the present. Open Court, La Salle 